\title{
Progress in the Development of Lightweight Nickel Electrode for Nickel-Hydrogen Cell
}

Doris L. Britton

Glenn Research Center, Cleveland, Ohio 
The NASA STI Program Office ... in Profile

Since its founding, NASA has been dedicated to the advancement of aeronautics and space science. The NASA Scientific and Technical Information (STI) Program Office plays a key part in helping NASA maintain this important role.

The NASA STI Program Office is operated by Langley Research Center, the Lead Center for NASA's scientific and technical information. The NASA STI Program Office provides access to the NASA STI Database, the largest collection of aeronautical and space science STI in the world. The Program Office is also NASA's institutional mechanism for disseminating the results of its research and development activities. These results are published by NASA in the NASA STI Report Series, which includes the following report types:

- TECHNICAL PUBLICATION. Reports of completed research or a major significant phase of research that present the results of NASA programs and include extensive data or theoretical analysis. Includes compilations of significant scientific and technical data and information deemed to be of continuing reference value. NASA's counterpart of peerreviewed formal professional papers but has less stringent limitations on manuscript length and extent of graphic presentations.

- TECHNICAL MEMORANDUM. Scientific and technical findings that are preliminary or of specialized interest, e.g., quick release reports, working papers, and bibliographies that contain minimal annotation. Does not contain extensive analysis.

- CONTRACTOR REPORT. Scientific and technical findings by NASA-sponsored contractors and grantees.
- CONFERENCE PUBLICATION. Collected papers from scientific and technical conferences, symposia, seminars, or other meetings sponsored or cosponsored by NASA.

- SPECIAL PUBLICATION. Scientific, technical, or historical information from NASA programs, projects, and missions, often concerned with subjects having substantial public interest.

- TECHNICAL TRANSLATION. Englishlanguage translations of foreign scientific and technical material pertinent to NASA's mission.

Specialized services that complement the STI Program Office's diverse offerings include creating custom thesauri, building customized data bases, organizing and publishing research results ... even providing videos.

For more information about the NASA STI Program Office, see the following:

- Access the NASA STI Program Home Page at http://wwww.sti.nasa.gov

- E-mail your question via the Internet to help@sti.nasa.gov

- Fax your question to the NASA Access Help Desk at (301) 621-0134

- Telephone the NASA Access Help Desk at (301) 621-0390

- Write to:

NASA Access Help Desk NASA Center for AeroSpace Information 7121 Standard Drive

Hanover, MD 21076 


\section{Progress in the Development of Lightweight Nickel Electrode for Nickel-Hydrogen Cell}

Doris L. Britton

Glenn Research Center, Cleveland, Ohio

Prepared for the

34th Intersociety Energy Conversion Engineering Conference sponsored by the Society of Automotive Engineers

Vancouver, British Columbia, Canada, August 1-5, 1999

National Aeronautics and

Space Administration

Glenn Research Center 


\section{Acknowledgments}

Jack Toon of Tritechnology Group of Bekaert Fibre Technologies is instrumental in providing us with the nickel fiber substrates.

This report is a formal draft or working paper, intended to solicit comments and ideas from a technical peer group.

This report contains preliminary

findings, subject to revision as analysis proceeds.

Trade names or manufacturers' names are used in this report for identification only. This usage does not constitute an official endorsement, either expressed or implied, by the National Aeronautics and Space Administration.

Available from

NASA Center for Aerospace Information 7121 Standard Drive

Hanover, MD 21076

Price Code: A02
National Technical Information Service 5285 Port Royal Road Springfield, VA 22100 Price Code: A02 


\title{
Progress in the Development of Lightweight Nickel Electrode for Nickel-Hydrogen Cell
}

\author{
Doris L. Britton \\ National Aeronautics and Space Administration \\ Glenn Research Center \\ Cleveland, Ohio 44135
}

\begin{abstract}
Development of a high specific energy battery is one of the objectives of the lightweight nickel-hydrogen $\left(\mathrm{Ni}-\mathrm{H}_{2}\right)$ program at the NASA Glenn Research Center. The approach has been to improve the nickel electrode by continuing combined in-house and contract efforts to develop a lighter weight electrode for the nickel-hydrogen cell. Small fiber diameter nickel plaques are used as conductive supports for the nickel hydroxide active material. These plaques are commercial products and have an advantage of increased surface area available for the deposition of active material. Initial tests include activation and capacity measurements at five different discharge levels, $\mathrm{C} / 2,1.0 \mathrm{C}, 1.37 \mathrm{C}, 2.0 \mathrm{C}$, and $2.74 \mathrm{C}$. The electrodes are life cycle tested using a half-cell configuration at 40 and $80 \%$ depths-of-discharge (DOD) in a low-Earth-orbit regime. The electrodes that pass the initial tests are life cycle-tested in a boilerplate nickelhydrogen cell before flightweight designs are built and tested.
\end{abstract}

\section{INTRODUCTION}

Future NASA missions will require long life, high power, and light weight energy storage systems which are beyond the capability of existing systems. NASA Glenn Research Center (NASA GRC) is currently involved in research in the area of electrochemical energy conversion and storage for space and terrestrial applications. The objective of this work is to achieve improved performance, higher specific energy, and longer life for electrochemical devices for space and terrestrial applications. One of the systems being studied is the nickel-hydrogen $\left(\mathrm{Ni}-\mathrm{H}_{2}\right)$ battery. The $\mathrm{Ni}-\mathrm{H}_{2}$ battery technology has progressed rapidly in recent years as a result of advanced designs and improved components. The $\mathrm{Ni}_{-} \mathrm{H}_{2}$ technology group at the NASA GRC has been working in the areas of the Individual Pressure Vessel (IPV), Common Pressure Vessel (CPV), as well as the bipolar system. One of the objectives of this program is reducing the weight of the components of the Ni- $\mathrm{H}_{2}$ system. To achieve this objective, extensive efforts are being made at NASA GRC to improve the components of the system both in-house and on contract.

\begin{abstract}
The major part of the technology development program focuses on the nickel electrode which, in addition to being identified as the most critical, has also been identified as the heaviest component of any nickel-based battery system such as nickel-hydrogen, nickelcadmium, nickel-zinc, and nickel-metal-hydride. The heavy-sintered nickel powder plaque has been the substrate of choice for many years to support the electrochemically-active material in these nickel-based batteries. The nickel powder plaque accounts for about half of the weight of the electrodes. Because of this shortcoming, NASA GRC took the initiative of originating an active program to improve the electrode weight by the use of lightweight plaques. NASA GRC has been developing nickel electrodes which will be 40 to $50 \%$ lighter in weight and have greater capacity for active material than the heavier state-of-the-art (SOA) sintered electrode.
\end{abstract}

\section{NICKEL FIBER PLAQUES}

Several factors affect the specific energy of a $\mathrm{Ni}-\mathrm{H}_{2}$ cell. One is the porosity of the nickel electrode. The specific energy of a Ni- $\mathrm{H}_{2}$ cell will increase by replacing the SOA sintered nickel electrode with the highly porous lightweight nickel fiber electrode. One advantage of the lightweight nickel plaques over the SOA sintered plaque is that the lightweight plaques can be easily manufactured with much larger pore sizes than the SOA plaques. Commercial SOA sintered nickel plaques are available in porosities of 80 to $86 \%$, while the lightweight nickel fibers are commercially available in porosities up to $98 \%$. Another limiting factor that will improve the specific energy of the $\mathrm{Ni}-\mathrm{H}_{2}$ cell is the nickel fiber size. Earlier Fibrex fiber plaque from National Standard (1), with fiber diameters between 22 and $25 \mu \mathrm{m}$ have a common feature of exhibiting a low initial utilization. Using smaller diameter nickel fiber materials can reduce this problem. The advantages of using these small nickel fibers are the significant increase in surface area available for deposition of active material and the improvement in the electrochemical accessibility to the active material. Another approach that will result in a higher specific energy of a Ni- $\mathrm{H}_{2}$ cell is to use thick nickel electrodes. Utilizing fewer thick nickel electrodes will reduce the number of other components, e.g., hydrogen electrodes and separators thus reducing the weight of
the cell. 
Several commercially available small fiber nickel materials were evaluated and tested in-house. After several preliminary experiments, four nickel fiber plaques were selected as promising support candidate for the nickel hydroxide active material. Preliminary results of the three of the four promising substrates, from MicroMetal Fiber Corporation (formerly Ribbon Technology Corporation), from Memtec America Corporation, and Auburn University, are reported earlier $(1,2)$. A new and improved nickel fiber substrate, developed and manufactured by Bekaert Fibre Technologies, was evaluated and tested at NASA GRC. This new substrate was manufactured for battery, fuel cell, and capacitor substrates and has been developed for electrode manufacturing processes. The substrate was manufactured by a proprietary wire bundle drawing process that produces the nickel fibers themselves. These fibers are drawn to a fiber diameter selected for optimum substrate performance. A novel formation process, which was developed over a period of years, is utilized to form the substrate precursor. The Bekaert nickel substrates are available in different fiber diameters ( 2 to $8 \mu \mathrm{m}$ ), thicknesses (30 to 80 mils) and porosities ( 85 to $95 \%$ ). Results of the test using this nickel fiber will be discussed in this report.

\section{ELECTROCHEMICAL IMPREGNATION}

The substrates are pretreated prior to impregnation in order to eliminate any surface contaminants that were obtained during handling and storage. The pretreated procedure used in this study is the wet oxidation cleaning treatment (3), which consists of heating the wet substrate at $350^{\circ} \mathrm{C}$ in air for 20 minutes. The cleaned substrates are then measured, weighed, and electrochemically impregnated in an aqueous bath containing $1.5 \mathrm{M}$ $\mathrm{Ni}\left(\mathrm{NO}_{3}\right)_{2}, 0.175 \mathrm{M} \mathrm{Co}\left(\mathrm{NO}_{3}\right)_{2}$, and $0.075 \mathrm{M} \mathrm{NaNO} \mathrm{Nade}_{2}$ acidic by the addition of $50 \%$ nitric acid. The bath is maintained at a constant temperature of $95-100^{\circ} \mathrm{C}$ and a $\mathrm{pH}$ of 3-4. The substrates are electrochemically impregnated for various periods of time (2 to 5 hours) and current densities (50 to $93 \mathrm{~mA} / \mathrm{cm}^{2}$ ) to determine the conditions needed to obtain the optimum loading level. The substrates are impregnated in a reaction vessel, which consists of a $600-\mathrm{ml}$ beaker containing a $400-\mathrm{ml}$ aqueous bath. The substrates are placed between two standard nickel counterelectrodes in a Teflon holder.

After impregnation, the impregnated substrates are formed by charging and discharging for $20 \mathrm{~min}$ at approximately the $3 C$ rate. The formation process serves to remove impurities, which are chiefly nitrates, carried over from the impregnation bath.

The in-house evaluation and testing work in the past year has been involved mainly with the new nickel fiber substrates from Bekaert Fibre Technology. Table 1 summarizes the electrochemical impregnation and initial cycle testing of these electrodes. A substrate thickness of 45 to 50 mils was used in this evaluation. The sample physical size was 25 square centimeters.

Loading levels of anywhere from 1.38 to $2.04 \mathrm{~g} / \mathrm{cm}^{3}$ void were obtained during the electrochemical impregnation procedure. The loading level is calculated based on the expanded thickness, porosity, substrate weight, and the difference between the substrate weight and the final weight after formation.

The thickness of these electrodes increased anywhere from 24 to $31 \%$ during impregnation. This is considerably more than the corresponding increase observed in standard sintered powder electrodes. This increase in thickness is a major factor affecting ultimate electrode performance. Minimizing this effect is essential for a long life space application. Considerable progress is currently being made in optimizing fiber substrate parameters as well as impregnation process to minimize this growth.

\begin{tabular}{lcccc}
\hline \multicolumn{1}{c}{ Nickel Electrodes } & D1 & D2 & D3 & D4 \\
\hline Loading level, g/cm ${ }^{3}$ void & 1.38 & 1.68 & 1.9 & 2.04 \\
Expansion, \% & 24 & 25 & 24 & 31 \\
Initial utilization, \% & 99 & 107 & 99 & 94 \\
Maximum utilization, \% & 116 & 114 & 114 & 104 \\
Specific energy, mAH/g & 181 & 222 & 209 & 215 \\
$\begin{array}{l}\text { Volumetric energy, } \\
\text { mAH/cm }\end{array}$ & 421 & 505 & 558 & 564 \\
\hline
\end{tabular}

Table 1. Electrochemical and Cycle Life Data of the Nickel Electrodes.

The utilization data is the ratio of the actual capacity to the theoretical capacity, expressed as a percentage. The actual capacity, in milliampere-hours (mAH), is determined by charging, in $\mathrm{KOH}$, at a constant $\mathrm{C}$ rate for 80 minutes, followed immediately by discharging at constant $1.37 \mathrm{C}$ rate to an end voltage of $-0.2 \mathrm{~V}$ against a $\mathrm{Hg} / \mathrm{HgO}$ reference electrode. The theoretical capacity is calculated from the finished active material weight in grams multiplied by the theoretical energy density of nickel hydroxide of $0.289 \mathrm{Ah} / \mathrm{g}$. The Bekaert nickel electrode obtained initial utilization of anywhere from $94 \%$ to $107 \%$, as seen in table 1. Earlier lightweight nickel electrodes with larger fiber diameter have a common feature of low initial utilization $(1,2)$. This shortcoming has been essentially solved by the use of the new and improved nickel fiber electrodes from Bekaert. Higher and longer sintering temperature and time than the earlier experimental substrates were used in developing these Bekaert nickel fibers.

The nickel-hydroxide active material has a theoretical specific energy of $289 \mathrm{mAH} / \mathrm{g}$. A typical state-of-the-art sintered nickel powder electrode has a theoretical specific energy of $120 \mathrm{mAH} / \mathrm{g}$. By comparison, the lightweight nickel fiber electrodes are up to $222 \mathrm{mAH} / \mathrm{g}$. An $85 \%$ increase in specific energy is a significant value in overall specific energy at the cell and battery level. 


\section{CYCLE LIFE}

Initial evaluation of the cycle life of the lightweight nickel electrodes is conducted in a half-cell configuration. The cell consists of a stack containing a Bekaert nickel fiber electrode as the cathode, a standard Eagle-Picher heavy sintered nickel electrode as the anode, a mercury/mercuric oxide $(\mathrm{Hg}-\mathrm{HgO})$ as the reference electrode, and a polypropylene as the separator. The stack is packaged in a 1-liter beaker filled with an excess of $26 \%$ potassium hydroxide $(\mathrm{KOH})$.

The electrodes are life cycle tested using a low-Earthorbit regime at $80 \%$ depth of discharge (DOD) which consists of a 55-minute charge at the $\mathrm{C}$ rate followed by a 35-minute discharge at the $1.37 \mathrm{C}$ rate $(\mathrm{C}$ is the capacity of the cell in ampere-hour). Failure of the electrode is defined as the point where the discharge voltage degrades to $-0.2 \mathrm{~V}$ against the $\mathrm{Hg} / \mathrm{HgO}$ reference electrode during the 35-minute discharge. After the end of life, the cell is disassembled and the components are visually inspected. Performance testing of the electrode at different discharge rates is conducted before and after the life cycle test. After a thorough rinsing and drying, the nickel electrode is weighed and the thickness measured.

Figure 1 shows the comparison in the utilization as a function of cycling of the nickel fiber electrodes with different loading levels. The initial utilization of these new and improved small-diameter fiber electrodes is about $40 \%$ higher than the earlier large-diameter fiber electrodes. The performance of the electrode with the heaviest loading level $\left(2.04 \mathrm{~g} / \mathrm{cm}^{3}\right.$ void) is lower than the other three electrodes. Electrodes loaded to $1.68 \mathrm{~g} / \mathrm{cm}^{3}$ void and $1.90 \mathrm{~g} / \mathrm{cm}^{3}$ void cycled for 1274 and 1974 respectively before they reached their end of life, which is mainly due to voltage degradation. Thicknesses of both electrodes doubled at the end of cycling. Both electrodes reached maximum utilization values of $114 \%$, which is equivalent to a specific energy of $211 \mathrm{mAH} / \mathrm{g}$ for the 1.68-loaded electrode and $209 \mathrm{mAH} / \mathrm{g}$ for the 1.90 loaded electrode.

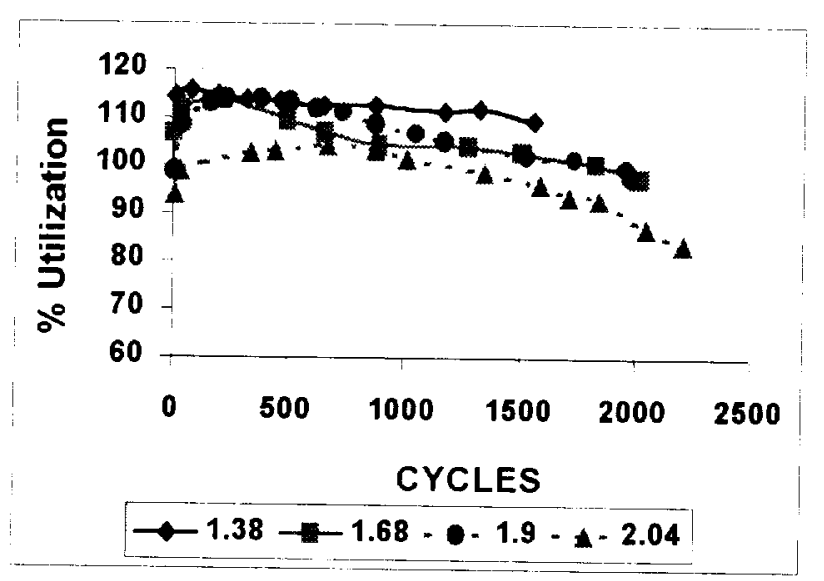

Figure 1. Utilization as a function of cycles.
To date, the least loaded electrode $\left(1.38 \mathrm{~g} / \mathrm{cm}^{3}\right.$ void) and the heaviest loaded electrode $\left(2.04 \mathrm{~g} / \mathrm{cm}^{3}\right.$ void) have over 1400 cycles ( $112 \%$ utilization) and 2200 cycles ( $95 \%$ utilization) respectively.

\section{ELECTRODE PERFROMANCE}

Performance testing of new and cycled electrodes is accomplished by capacity measurements at various discharge rates $(0.5,1.0,1.37,2.74 \mathrm{C})$ after charging at a $C$ rate for 80 minutes. Figure 2 shows results of this testing. The utilization of the heavier-loaded electrodes (1.90 and $2.04-\mathrm{g} / \mathrm{cm}^{3}$ void) varies with discharge rate exhibiting lower values at the higher rates. This dependency is not as drastic with the lighter-loaded electrodes ( 1.38 and $1.68 \mathrm{~g} / \mathrm{cm}^{3}$ void).

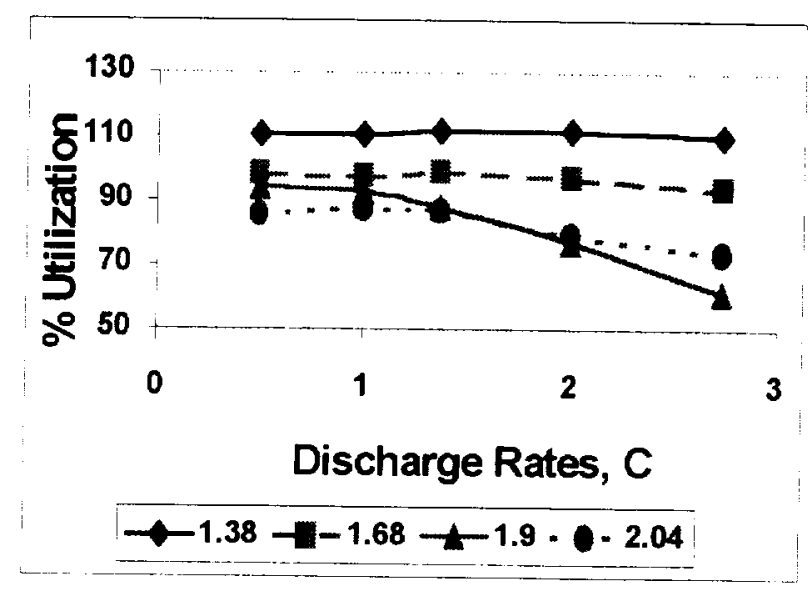

Figure 2. Nickel fiber electrode utilization as a function of discharge rates.

Since the 1.68 and 1.90-loaded electrodes reached their ends of life, as mentioned above, the comparison of the performance of these electrodes, new and cycled, at different discharge rates is represented in figure 3 . In general, these nickel fiber electrode demonstrated better performance after being cycled. The utilization values of the new 1.68-loaded electrode at the different discharge rates are almost similar. The values increased after the electrode has been cycled for over 2000 cycles with a larger difference in the lower rates. In the case of the 1.90 -loaded electrode, the utilization at the higher rate $(1.37 \mathrm{C})$ is about $34 \%$ lower than the lower rate $(\mathrm{C} / 2)$ for both the new and cycled electrode. An almost parallel increase in utilization values of $11 \%$ is also shown for all discharge rates after cycling for the 1.90-loaded electrode. 


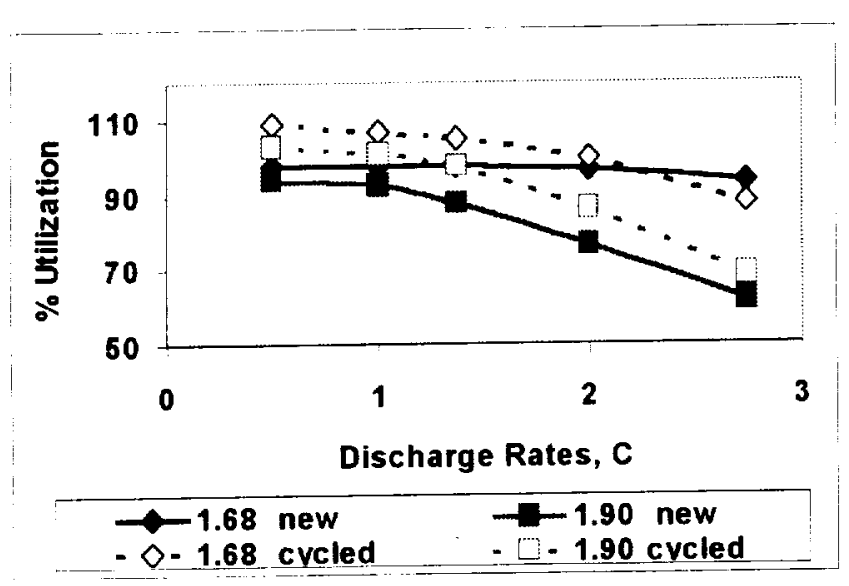

Figure 3. Utilization data as a function of discharge rate for new and cycled nickel fiber electrodes.

\section{CONCLUSION}

Improving performance and cycle life as well as increasing the specific energy of the $\mathrm{Ni}-\mathrm{H}_{2}$ system are the main thrust of the technology program at NASA GRC. One of the ways of achieving these goals is by developing lightweight nickel electrodes.

Initial problems associated with lightweight plaques, such as low loading levels and low initial utilization, have been solved by the use of small diameter nickel fibers and altering substrate manufacturing process. The use of these nickel fibers results in a significant increase in the surface area available for deposition of active material without a significant reduction in void volume. Superior performance of these nickel fiber electrodes has been demonstrated.

The issue of expansion during impregnation and cycling, resulting in premature electrode failure, needs to be investigated. Nickel fiber substrates with different properties are currently being evaluated in-house.

\section{ACKNOWLEDGMENTS}

Jack Toon of Tritechnology Group of Bekaert Fibre Technologies is instrumental in providing us with the nickel fiber substrates.

\section{REFERENCES}

1. "Development of Lightweight Nickel Fiber Electrodes for Nickel-Based Systems", Britton, D.L., Proceedings of the 32nd Intersociety Energy Conversion Engineering Conference, Honolulu, HI, July 27-August 1, 1997.

2. "Performance of Lightweight Nickel Electrodes," Britton, D.L., Proceedings of the 33rd International Power Sources Symposium, Cherry Hill, NJ, June 1988, NASA TM 100958 .

3. "Methods of Producing Electrodes for Alkaline Batteries," Beauchamp, R.L., et.al, U.S. Patent 4,032,697, June 28, 1977.

4. "High Energy Density Micro-Fiber Based Nickel Electrode," Coates, D.K., et.al, Proceedings of the 12th International Rechargeable Battery Symposium, Deerfield Beach, $\mathrm{Fl}$, March 1995.

5. "High Surface Area, Low Weight Composite Nickel Fiber Electrodes," Johnson, B.A., et.al, Proceedings of the Space Electrochemical Research and Technology, NASA, Cleveland, $\mathrm{OH}$, April 1993. 
Public reporting burden for this collection of information is estimated to average 1 hour per response, including the time for reviewing instructions. searching existing data sources. (hathering and maintaining the data needed. and completing and reviewing the collection of information. Send comments regarding this burden estimate or any other aspect of this

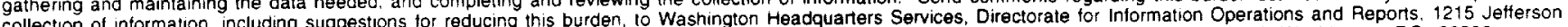
Davis Highway, Suite 1204. Arlington. VA 22202-4302, and to the Office of Management and Budget, Paperwork Reduction Project (0704-0188), Washington, DC 20503.

\begin{tabular}{l|l|l|} 
1. AGENCY USE ONLY (Leave blank) & 2. REPORT DATE & 3. REPORT TYPE AND DATES COVERED
\end{tabular}

\begin{tabular}{|c|c|c|}
\hline 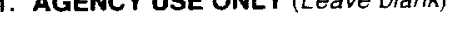 & $\begin{array}{l}\text { 2. REPUHA } 1999 \\
\text { September }\end{array}$ & Technical Memorandum \\
\hline
\end{tabular}

\section{TITLE AND SUBTITLE}

Progress in the Development of Lightweight Nickel Electrode for

Nickel-Hydrogen Cell

6. AUTHOR(S)

Doris L. Britton

\section{FUNDING NUMBERS}

WU-632-1A-1B-00

8. PERFORMING ORGANIZATION REPORT NUMBER

$E-11867$

National Aeronautics and Space Administration

John H. Glenn Research Center at Lewis Field

Cleveland, Ohio 44135-3191

10. SPONSORING/MONITORING

AGENCY REPORT NUMBER

National Aeronautics and Space Administration

Washington, DC 20546-0001

NASA TM-1999-209430

SAE 99-01-25.37

11. SUPPLEMENTARY NOTES

Prepared for the 34th Intersociety Energy Conversion Engineering Conference sponsored by the Society of Automotive Engineers. Vancouver. British Columbia, Canada, Augusi 1-5, 1999. Responsible person, Doris L. Britton, organization code 5420. (216) 433-5246, fax (216) 433-6160, (E-mail: Doris.L.Britton@ grc.nasa.gov).

12a. DISTRIBUTION/AVAILABILITY STATEMENT

12b. DISTRIBUTION CODE

Unclassified - Unlimited

Subject Categories: 26 and 44

Distribution: Nonstandard

This publication is available from the NASA Center for AeroSpace Information. (301) 621-0390.

13. ABSTRACT (Maximum 200 words)

Development of a high specific energy battery is one of the objectives of the lightweight nickel-hydrogen $\left(\mathrm{Ni}-\mathrm{H}_{2}\right)$ program at the NASA Glenn Research Center. The approach has been to improve the nickel electrode by continuing combined in-house and contract efforts to develop a lighter weight electrode for the nickel-hydrogen cell. Small fiber diameter nickel plaques are used as conductive supports for the nickel hydroxide active material. These plaques are commercial products and have an advantage of increased surface area available for the deposition of active material. Initial tests include activation and capacity measurements at five different discharge levels, C/2, 1.0C, 1.37C. 2.0C, and 2.74C. The electrodes are life cycle tested using a half-cell configuration at 40 and $80 \%$ depths-of-discharge (DOD) in a lowEarth-orbit regime. The electrodes that pass the initial tests are life cycle-tested in a boilerplate nickel-hydrogen cell before flightweight designs are built and tested.

14. SUBJECT TERMS

Nickel; Electrodes: Lightweight; Life cycle; Nickel-hydrogen

\begin{tabular}{|c|c|}
\hline $\begin{array}{c}\text { 17. SECURITY CLASSIFICATION } \\
\text { OF REPORT } \\
\text { Unclassified }\end{array}$ & $\begin{array}{c}\text { 18. SECURITY CLASSIFICATION } \\
\text { OF THIS PAGE } \\
\text { Unclassified }\end{array}$ \\
\hline
\end{tabular}

NSN 7540-01-280-5500

19. SECURITY CLASSIFICATION OF ABSTRACT

Unclassified

\begin{tabular}{|c|c|}
\hline & $\begin{array}{c}\text { 15. NUMBER OF PAGES } \\
10\end{array}$ \\
\hline & 16. PRICE CODE \\
\hline & $\mathrm{A} 02$ \\
\hline $\begin{array}{l}\text { SECURITY CLASSIFICATION } \\
\text { OF ABSTRACT }\end{array}$ & 20. LIMITATION OF ABSTRACT \\
\hline Unclassified & \\
\hline
\end{tabular}

